Australian Journal of

Educational Technology

\title{
Multimedia markets: A study of Australian content developers
}

\author{
Dean Jason Noacco \\ University of Wollongong \\ d.noacco@uow.edu.au
}

\begin{abstract}
The Australian multimedia industry needs to pay closer attention to original market-driven content development if it is to survive an increasingly competitive global marketplace. This paper provides a schema for future developments in multimedia and reports some results of an investigation of multimedia content developers in terms of size, composition, information flows, types of activities undertaken, technological orientation and project focus. The aims of the study were to provide a "snapshot" of the industry at the current time, to serve as a benchmark for future research, and map current industry activities against predicted trends in multimedia. The results have implications for government programs supporting new multimedia ventures, and for present policy and strategy mechanisms employed by multimedia producers.
\end{abstract}

Since 1983 the Australian software industry has greatly benefited from taxation concessions and government grants directed at high technology enterprises, the "sunrise" industries touted by Barry Jones during that year's election campaign. Interactive multimedia is currently enjoying the same level of popularity, interest and support from both the private and public sectors, with little apparent understanding of the industry's composition or likely future. The Broadband Services Expert Group's final report Networking Australia's Future; the Australian Science and Technology Council's report on Australia's Research Networks, The Networked Nation; the Employment and Skills Formation Council's discussion paper on converging communications and computer technologies, and the former Prime Minister's cultural statement Creative Nation illustrate but a few of the recent investigations that earmark multimedia as a strategic concern for Australia in coming years.

While noting the desirable benefits from a prosperous multimedia industry, and using the usual mix of cultural and economic arguments to sustain claims of catching the global "content wave", policy has failed 
adequately to address the same problems that plagued software development generally in 1983, and which will ultimately affect multimedia development in years to come. It is original, market-driven content that will establish Australia as a centre for excellence in interactive multimedia and industry policy should be directed towards this aim. An understanding of multimedia markets, the current state of Australian multimedia producers, and the likely direction of content production are important considerations for the future of the industry.

\section{An economic imperative}

The central reason behind targeting multimedia as a strategic interest for Australian content development are the economic gains to be made. As a new and popular means of entertainment, differentiated from existing forms through the addition of interactivity, multimedia has the capacity to generate significant export revenues for Australia. At present the global market is characterised by the dominance of the United States, and Australia is a minor player in what many analysts describe as the "born global" industry.

The Commerce in Content report estimated that the Australian content industries are currently valued at $\$ 8.4$ billion, while the domestic interactive multimedia market may be valued at $\$ 500$ million per annum. To gain an appreciation of the size of the Australian market, it is worth considering the number of multimedia publishers in Australia, as accurate statistics on the number of titles produced are difficult to obtain. In 1994 Australia had 29 CD ROM publishers, representing approximately 2 per cent of the world market.[1] The entire Asia/Pacific sector (where Japan dominates) represented 7.4 per cent, North America 46 per cent, and Europe 46.3 per cent. The success of a mass-market title is dependent on its acceptance by the North American market where a best seller will ship 500,000 units compared to 20,000 in Australia. Not surprisingly 45 per cent of multimedia developers are in North America, and only 9 per cent in Australasia.[2]

The economic arguments for Australian multimedia content development are further strengthened by the remarkable growth in the multimedia appliance industry, including CD ROM drives, and multimedia-capable desktop computers. US research firm Market Vision estimates that the multimedia appliance industry is anticipated to grow from $\$ 250$ million in 1992 to $\$ 15$ billion by 1997. Microsoft's Bill Gates anticipates the world CD ROM .market to double annually for the next three years. Indeed Australian CD ROM pressings grew from 40,000 in 1992 to 250,000 in 1993, with an expected target of 1,000,000 reached in 1994,[3] providing further support for the strong economic bias to support an indigenous multimedia industry. These sentiments were reflected in the former Prime Minister's launch of Creative Nation: 
We can, for instance, if we move rapidly, gain a significant share of the CD ROM market. In the longer term, though not very much longer, we can create a dynamic multimedia industry in Australia.[4]

The cultural arguments

Adding further weight to economic imperatives, several cultural arguments have been given credence in the pursuit of a uniquely Australian multimedia industry. The Labor Government's cultural policy stated that:

What is distinctively Australian about our culture is under assault from homogenised international mass culture .... The revolution in information technology and the wave of global mass culture potentially threatens that which is distinctly our own. In doing so it threatens our identity and the opportunities this and future generations will have for intellectual and artistic growth and self expression.[5]

These words have led to not only an economic imperative, but a cultural necessity for an Australian multimedia industry. Moves for the establishment of the Australian Multimedia Enterprise (AME), funding of the Australia on CD program, and $\$ 252$ million in multimedia arts initiatives under the Creative Nation program were justified under the auspices of cultural dynamism.

\section{Towards a conceptual schema for understanding multimedia markets and drivers}

The lessons of past discontinuous convergent technologies provide valuable lessons for the new emerging markets of multimedia. The "market" for multimedia is in itself a misnomer, representing the convergence of six separate but increasingly related strategic industries: telecommunications; broadcasting (television and radio); film and video; print and publishing; computers; and consumer electronics. In 1993 the major sectors of this digital convergence totaled over $\$ 900$ billion,[6] and while we have the experience of hundreds of years of analogue, we have much to learn about building a digital world for the future.

Broadly speaking there are three main waves of content production which will be developed over the next two decades: CD ROM, followed by online PC services, then broadband interactive services. Understanding the success of CD ROM over this period provides the key to understanding the development of the other two waves of content production. A conceptual schema has been developed to map the development of multimedia markets in Figure 1.

In phase one technology drives the market; hardware installations, purchases of multimedia capable machines, and peripheral devices such as CD ROM drives are responsible for the rapid growth of multimedia. Necessarily there is a time lag between the development, purchase and 
utilisation of the new technology before content producers are best able to use the unique features that multimedia has to offer, and adapt to the limitations of CD ROM (primarily speed and storage capacity) where the market reaches phase two. As CD ROM drives reach a critical installed base and developers became familiar with the technology, content is the critical determinant for the success of new titles, primarily through "repurposing" existing content and "republishing" on CD ROM (phase three). The final phase involves excellence in content, as new market driven content "pushes the envelope" of the medium, employing innovative techniques, new forms of immersiveness and interactivity and significant features that differentiate the product from existing offerings. Titles are platform independent, able to deployed using a variety of mediums and network technologies, and consumer demand drives the direction of the market.

The justification for adopting this particular framework in analysing multimedia markets stems from the observation that the market for interactive multimedia products is still in its infancy. Dataquest, a leading research firm in the field, compares multimedia to televisions and VCRs. Both technologies took approximately ten years for developers to take advantage of the hardware and for manufacturers to simultaneously improve quality and reduce prices to obtain a critical mass market.[7]

\section{The current state of play}

The conceptual schema is a useful tool in plotting the current direction of multimedia markets. A tentative analysis currently puts multimedia between phases three and four using this model. The available evidence indicates that a critical mass market for CD ROM has been satisfied, sales of multimedia capable equipment and titles are growing, the market is suffering from an oversupply of poor quality and "repurposed" content, consumer demand is driving the market, and excellence in content is a key indicator of title success. The market does not appear to have reached platform independent production or be delivering using alternative transmission modes in sufficient quantity to warrant claims of a second mass market in mid-band or broadband services for example.

\section{Towards a critical mass market}

The primary factor behind the growth of CD ROM up to phase three, though the technology has existed since the late 1980s, has largely been due to a drop in drive prices worldwide, critical to developing a mass market in the area and affordable for a much broader consumer population. In the US there are those who believe that 1996 is the first year that the multimedia CD ROM market will have reached a suitable size to be classified as a mass market. Tamer, in tracing the development of the 
industry notes that the market for CD ROM grew to only 900,000 in 1992, but quadrupled to 3.6 million by year-end 1993.[8] In 1993, the number of CD ROM drives shipped with home computers exceeded 2 million.[9] Dataquest predicted that the number sold worldwide in 1993 was over 4.8 million.[10] The combined revenue of titles and readers in that same year was estimated at US $\$ 12.2$ billion when the number of titles grew from 5,283 to 8,149 and sales growth was estimated to reach $\$ 144$ billion by 1999.[11] Inteco corporation forecasts that 1995 CD ROM drive sales will be 10 million units, comprising 2.5 million in Europe and 1 million in Japan. Following these trends, the home market installed-base will reach 40 million units in the US, 11 million in Europe and 5 million in Japan by 1997.[12]

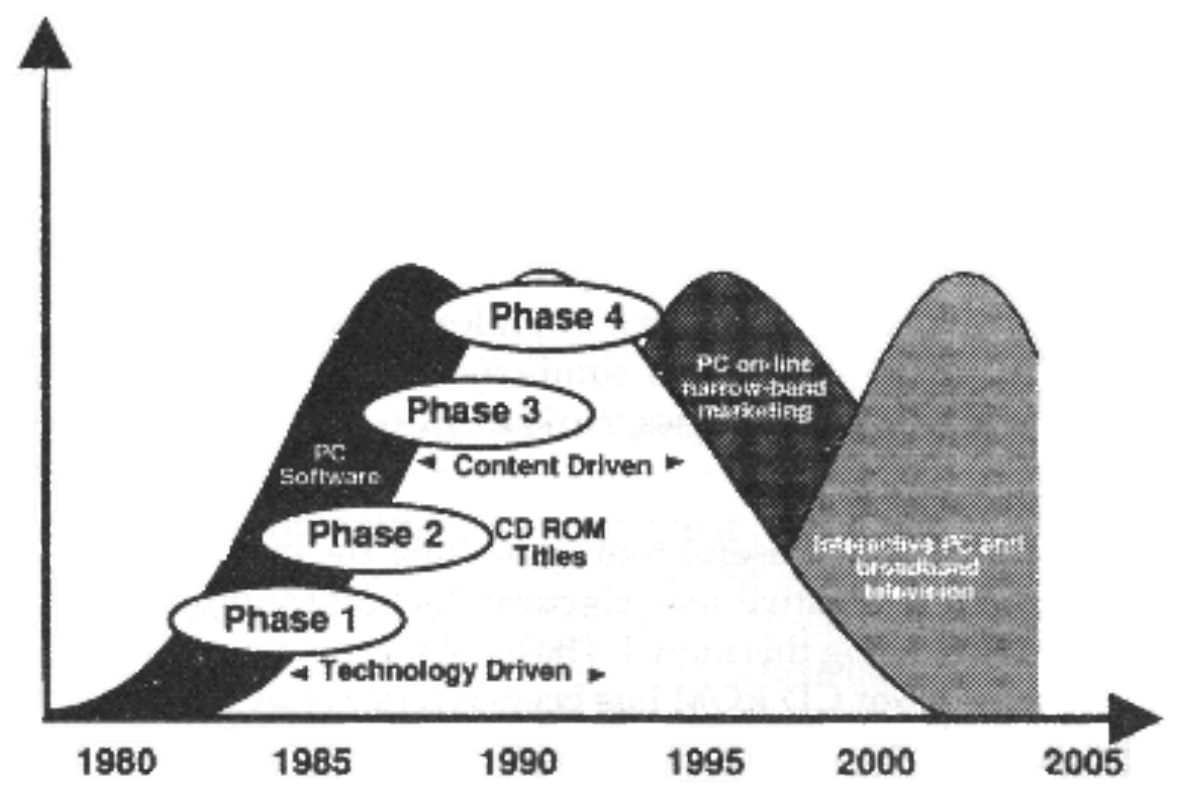

Figure 1 Conceptual schema of multimedia markets

According to data recently released by the Software Publisher's Association for the first quarter of 1994, sales of software on compact discs rose from \$29.1 million in the first quarter of 1993 to $\$ 135.8$ million in the first quarter of 1994, a 366\% increase. Dataquest says there will be 23.6 million CD ROM drives in place by the end of 1994. By 1996, Dataquest predicts $36.6 \%$ of desktop PCs will include CD ROM drives, while the current installed base for CD ROMs is only 20 per cent.[13] Will this installed technology base reach the critical point required for mass market title development? Some observers indicate that this will have been reached in early 1995, with a mature 10 million player market allowing specialist and niche market publications to become viable.[14] 
Consumer interests are key

The two main types of content publishing at present are consumer titles and business reference materials. The latter is mostly concerned with compiling databases of business information onto CD ROM, and few exciting business applications have appeared to date. Market Vision's recent study of multimedia applications and markets estimates the combined US/European market for computer-based multimedia at \$3 billion in 1994, $\$ 5$ billion in 1995, and $\$ 10$ billion in 1996. The balance between business and consumer usage was touted at an even 50 per cent each, with business usage favoured to grab the lion's share by 1996.[15] According to Dataquest, business usage alone accounted for $\$ 3$ billion, dwarfed by consumer interests of $\$ 17$ billion.[16] Such analyses ignore the fact that the majority of business market CD ROMs are not interactive multimedia titles in any sense of the term: Infotech estimates that almost half of all CD ROM titles consist of structured data in record format, such as computer output, inventory and parts lists, and financial information, with the next most prevalent use being for full-text storage.[17] TFPN Publishing considers only one-third of the titles on the market today as multimedia.[18]

There were 9,500 CD ROM titles on the international market in late 1994,[19] a minimum of 250 titles are released worldwide each month, and a typical US retailer carries only 30-50 titles.[20] The Washington-based Software Publishers Association's CD Software Sales Report notes total CD ROM disc sales were $\$ 139.6$ million, up 421 per cent from the second quarter of 1993. The consumer market is currently attracting the most attention, with the Association noting that three of these categories totaled $\$ 102$ million for the first quarter of 1994 [21], followed by a 392 per cent rise in video games alone to US\$23.86 million in the second quarter of 1994.[22] Analysts in the computer storage industry believe that 75 percent of CD ROM drives will be sold to home users, signalling further growth for the consumer market,[23] adding further support to the influence of consumer interests as a key driver for the industry.

Within the multimedia community, these sentiments are reflected in the actions of key content developers, Microsoft included, that are leveraging their presence in this sector. Sony America believe that the 10 million or so installed base of CD ROM drives make the market closer to the consumer TV industry, providing an economic base in which people can try new ideas, possibly supplying a solid entertainment platform for the future.[24] Microsoft, spurred by the success of the 50 or so consumer titles released under its "Home" Banner, and its expectation that the average consumer will buy 5 or more multimedia titles a year, has doubled its consumer division from 700 to 1400 people during fiscal 1995. Other industry leaders, including Compton's New Media, are also looking toward the consumer, stressing that quality and content are key to success in this market. 


\section{A future of excellence in content}

It should come as no surprise that only 4 per cent of CD ROM titles break even in the marketplace. The main thrust of the 9,500 or so titles on the market today has been, adopting the industry terminology, to "repurpose" existing content contained in print, audio or video form, and transpose this information into digital data on CD ROM. While such strategies may have been appropriate during the emerging phases of multimedia production where severe skill shortages, a lack of understanding of the capabilities of the technology, and the scarcity of venture capital to fund new and innovative endeavours precluded creative uses of the medium, the market is saturated with poor quality content, and ready for the next phase of multimedia publishing.

What will this next phase look like? Above all it will involve innovative, consumer-driven uses of the technology that take advantage of the interactive nature of the new technology and satisfy consumer needs for information, education, and entertainment. Already we can see this trend emerging with a shakeout of title developers imminent. Charlotte Guyman, general manager of lifestyle products at Microsoft, says that her division follows a three-part formula in order to ensure the commercial success of titles: paying close attention to quality, ensuring the compelling nature of a title, and taking advantage of the new ways of exploring information offered by the multimedia format to provide a unique experience.[25] Australia's most recent study of international trends in investment and strategic alliances focused on multimedia content, Excellence in Content, reported that the best chance of international success involves leveraging excellence in four areas: compelling nature, instructional design, interface design, and quality control.[26]

Concerns about the rapid development of titles extend far beyond "repurposed" content however. Some analysts believe that many entertainment titles are too expensive, do not run correctly, are poorly designed, or feature content of little interest to most people.[27] Others have discovered that programming bugs, incompatibility problems, speed, memory troubles, deceptive packaging and unresponsive vendors top this list of complaints.[28] Yet more claim that poor installation, interface and navigation difficulties and inferior interaction and discovery paths do little to interest users.[29] Such claims add up to a title bearing the tag "shovelware": poorly designed software pieced together from pre-existing content.

The definitive content market for multimedia material is the knowledge producing institutions of the world - traditional colleges or universities. A testament to the lack of quality in current offerings stems from a recent survey by the Association of American Publishers of Faculty and Students' Opinions of the Value and Use of Textbooks. While 34 per cent of college students own a multimedia capable computer, only a quarter of professors in the survey agreed with the statement "computer-based multimedia 
instruction promises to be a better means for delivering course content."[30] Lending further support to the poor quality of multimedia content today, more than 70 per cent of the institutions surveyed in the 1994 CAUSE Institution Database Survey responded that less that 10 per cent of professors were using multimedia software in the classroom.[31]

Clearly the key to success in the next phase of multimedia production lies not in leveraging the technology, distribution channels, or the ultimate form of the product, but using original content to add value to a company's multimedia offerings, regardless of its format. More importantly multimedia producers should be seeking to leverage this original content regardless of its format, as new digital mediums such as online services, broadband interactive, and digital television take hold, replacing the use of $\mathrm{CD}$ ROM as the primary delivery platform.

\section{An investigation of Australian firms}

Between May and July 1995 a pre-tested questionnaire was mailed to 140 Australian multimedia content producers identified with the assistance of the Australasian Interactive Multimedia Industry Association. For each firm the nominated person was invited to complete four sections: corporate profile, employee profile, project base, and networking indicators. Several key questions guided the research exercise:

- What is the organisational structure of the Australian multimedia content development community?

- What activities are undertaken by these organisations?

- What are the typical indicators that characterise multimedia content development within these organisations?

The format of the survey emphasised close-ended questions, and the respondent was encouraged to select "other" where the alternatives did not suit the firm's experience. The remainder of questions employed nominal data collection where respondents were required to provide figures where available, from the firm's experience. 55 firms responded to the questionnaire including one invalid return, yielding an effective return of 54 questionnaires.

\section{Organisation indicators}

The types of activity specialisation of firms in our sample are outlined in Table I indicating the broad scope of activities undertaken. Over half of all respondents nominated interactive multimedia training and education alongside information kiosks and directories, providing a strong indication of the core strengths of Australian firms. It is significant at this stage to note that less than 40 per cent of respondents nominated commercial CD ROM titles as a specialisation: this feature of the industry does not vie well with the perception that Australia can take advantage of mass markets in multimedia applications on a global scale, limiting the export potential of consumer titles. 
Table I Organisation product and service focus

End Product/Service Focus No. of firms $\%$ of firms Interactive multimedia training and education $\begin{array}{ll}31 & 57.41 \% \\ 28 & 51.85 \%\end{array}$ Information Kiosks / Directories $38.85 \%$

Commercial CD ROM titles

$35.19 \%$

Customised client or cross platform solutions

Niche market titles

Corporate Presentations/Demonstrations / brochures

$35.19 \%$

Multimedia front ends

$33.33 \%$

Other

$22.22 \%$

On-line-services

On-line documentation/help systems/manuals

Systems Integration

Republishing/re-packaging for the local market

$22.22 \%$

$20.37 \%$

$14.81 \%$

$11.11 \%$

The activity specialisations of firms appears to correlate with the industry specialisations of respondents as set out in Table II. This table indicates that the education and government sectors dominate the focus of Australian organisations in the sample; consumer products such as entertainment systems, home reference titles and games represent approximately 40 per cent reflecting the lower activity focus in commercial and niche CD ROM titles at approximately the same level. At the other end of the spectrum, Table I demonstrates that less than 6 per cent of firms are concentrating on adapting overseas content for the local market, with a bias towards customised client solutions (35 per cent), furthering limiting the potential for the creation of mass market titles appropriate for overseas audiences.

Table II Organisation industry specialisation

\begin{tabular}{|c|c|c|}
\hline Industry Specialisation & $\begin{array}{l}\text { No. of } \\
\text { firms }\end{array}$ & $\%$ of firms \\
\hline Education & 35 & $64.81 \%$ \\
\hline Government (Federal/State/Local/Military) & 28 & $51.85 \%$ \\
\hline Consumer Products (Durable Goods / Entertainment Systems) & 22 & $40.74 \%$ \\
\hline Publishing (Broadcast/Print/ or Electronic) & 18 & $33.33 \%$ \\
\hline Health Care & 17 & $31.48 \%$ \\
\hline Finance (Insurance/Banking/ Accounting) & 12 & $22.22 \%$ \\
\hline onal Services (non-computer Consulting) & 11 & $20.37 \%$ \\
\hline e or Retail Distribution (non-computer) & 11 & $20.37 \%$ \\
\hline Industrial Manufacturing (Heavy Equipment/Machine Tools) & 8 & $14.81 \%$ \\
\hline Other & 8 & $14.81 \%$ \\
\hline Aerospace/Aeron & 7 & $12.96 \%$ \\
\hline Materials Processing (Chemical Agriculture/Construction) & 7 & $12.96 \%$ \\
\hline Legal Services & 6 & $11.11 \%$ \\
\hline Scientific or Technical Instruments Manufacturing & 6 & $11.11 \%$ \\
\hline Engineering (Mechanical/Electrical/Civil) & 5 & $9.26 \%$ \\
\hline
\end{tabular}


The Multimedia Content Activity Specialisations of respondents are set out in Table III. The majority of firms ( $>75$ per cent) concentrated on design and development aspects of projects, with a lesser emphasis on Management Consultancy and Post-production services (33 and 22 per cent respectively), a task generally outsourced to contractors and consultants. Several firms cited business development as an important aspect of project planning and design, possibly reflecting the poor relationship between project initiation and profitability as set out in the histogram of one year cumulative multimedia project life cycle in Figure II.

Table III Organisation content development activity specialisation

\begin{tabular}{lcc} 
Activity Specialisation & No. of firms & $\%$ of firms \\
\hline Project planning and design & 42 & $77.78 \%$ \\
Writing, scripting and title development & 41 & $75.93 \%$ \\
Authoring / Programming & 39 & $72.22 \%$ \\
Instructional / Interface design & 33 & $61.11 \%$ \\
Graphics / visual design / animation & 33 & $61.11 \%$ \\
Video, audio and other media services & 30 & $55.56 \%$ \\
Management Consultancy & 18 & $33.33 \%$ \\
Post-production services & 12 & $22.22 \%$ \\
Other & 4 & $7.41 \%$ \\
\hline
\end{tabular}

Organisations identified 321 multimedia project conducted in the past calendar year that went through the process of concept design and testing. Only 60 per cent of these (193) projects reached the phase of commercialisation, a period where the project is presented to a client (in the case of customised implementation) or brought to the market (in the case of commercial or niche market titles). Given the high rate of customised solutions performed for contract work versus the number of commercial titles outlined in Table I involving significant risk undertakings in bringing a title to market, it is postulated that the majority of commercial titles fail the test of business planning and are subsequently abandoned. Of those projects that proceed beyond commercialisation, only 35 per cent of the original entrants (111 projects) broke even within the past year, and 31 per cent became profitable (101 projects). While the study did not examine the precise mix of projects that involved work for hire (customised solutions or systems integration for example) and those that involved new market development and subsequently higher risks (consumer entertainment titles for example), such information would provide a more holistic picture of the relationship between market entry and profitability. A general benchmark figure provided by multimedia market research organisations is that only 4 per cent of all commercial multimedia titles reach profitability. The substantially higher figure observed here, in the 31 per cent range for this particular study, appears to 
suggest that there is a greater mix of projects that involve lower risk, possibly in the domain of work for hire or customised client solutions, as opposed to riskier endeavours that involve more careful business planning.

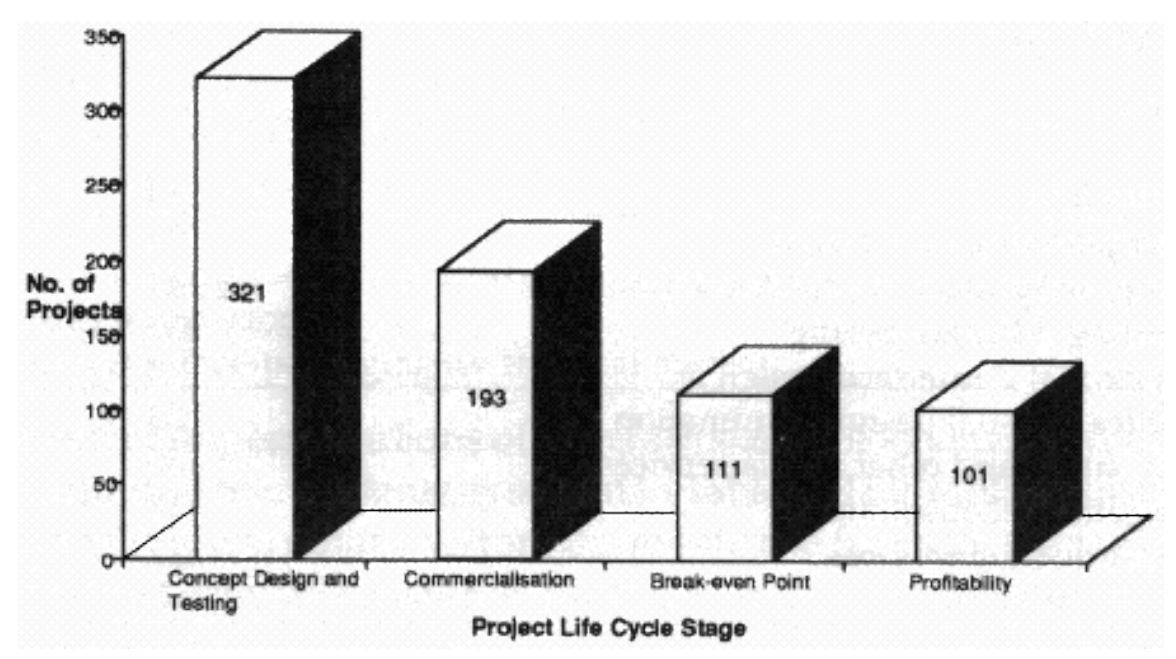

Figure II One year cumulative multimedia project life cycle

The market focus of current and new project undertakings is set out in Table IV. The vast majority of firms ( $<90$ per cent $)$ cited the domestic Australian and New Zealand market as the primary focus for current and future business development, with over one-third of respondents concentrating exclusively on this market. Not surprisingly, a high proportion of firms sought to leverage their investment in generic solutions for this market and "republish" in the other English speaking nations of Europe and North America ( $>50$ per cent). The Asian market was also identified as a key interest for 44 per cent of firms, though this was not reflected in respondent's interest or indeed their capability to publish in non-English speaking languages. One niche producer even develops Spanish language titles for the domestic market, providing some indication of the breadth of geographic and language focus of the group.

Table IV Market focus

\begin{tabular}{lcc} 
Geographic Focus & No. of firms & $\%$ of firms \\
\hline Domestic (Australian/New Zealand Market) & 47 & $87.04 \%$ \\
European/North American Market & 29 & $53.70 \%$ \\
Asian Market & 24 & $44.44 \%$ \\
\hline Language Focus & No. of firms & $\%$ of firms \\
\hline English Language Titles & 28 & $51.85 \%$ \\
Non-English Language Titles & 18 & $33.33 \%$ \\
Not Specified & 8 & $14.81 \%$ \\
\hline
\end{tabular}




\section{Production demographics}

The following provides general information about the size and incorporation of organisations surveyed in terms of the number of employees, annual turnover, age and company status. Table compares the respondent organisations in terms of the number of employees/ contractors/or consultants it currently engages. Just under half of all organisations were small concerns involving the work of 1-5 people (48 per cent), tapering gradually to $51-100$ employees (1.85 per cent), and rising slightly to those that employed more than 100 people ( 9 per cent). Table III indicates the annual turnover of respondent organisations. Five firms declined to provide such details, but the results indicate a fairly broad spread of results, peaking at the greater than $\$ 1,000,000$ turnover mark. Figure III depicts the spread of organisation age, with the majority (56 per cent) of firms between one and five years old. Approximately 15 per cent of firms were new entrants to the market, being less than one year old. Table V portrays the incorporation of business activities, with 51 per cent of all players incorporated as a private company, and a significant proportion (18 per cent) defined as government institutions (10 responses).

While it is difficult to generalise on these results, given the broad descriptors used in the survey, the typical firm may be described as a relatively small concern, employing one to five persons (48 per cent), have an annual turnover between $\$ 100,000$ and $\$ 1,000,000$ (50 per cent), be one to five years in age (56 per cent) and incorporated as a private company (51 per cent).

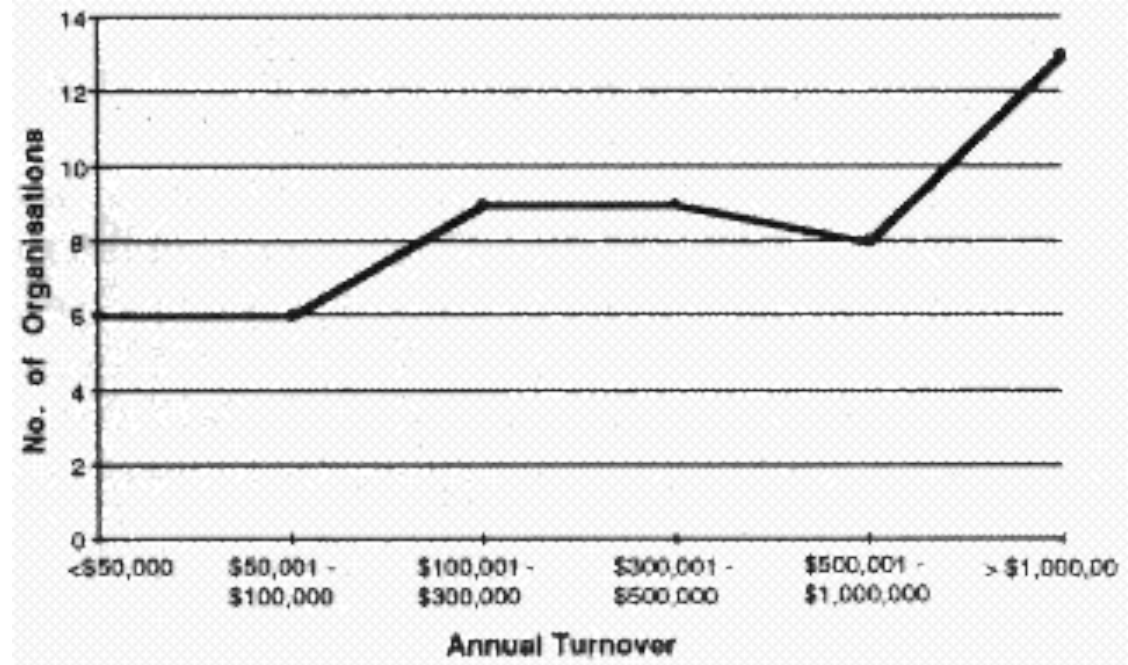

Figure III Organisation annual turnover 


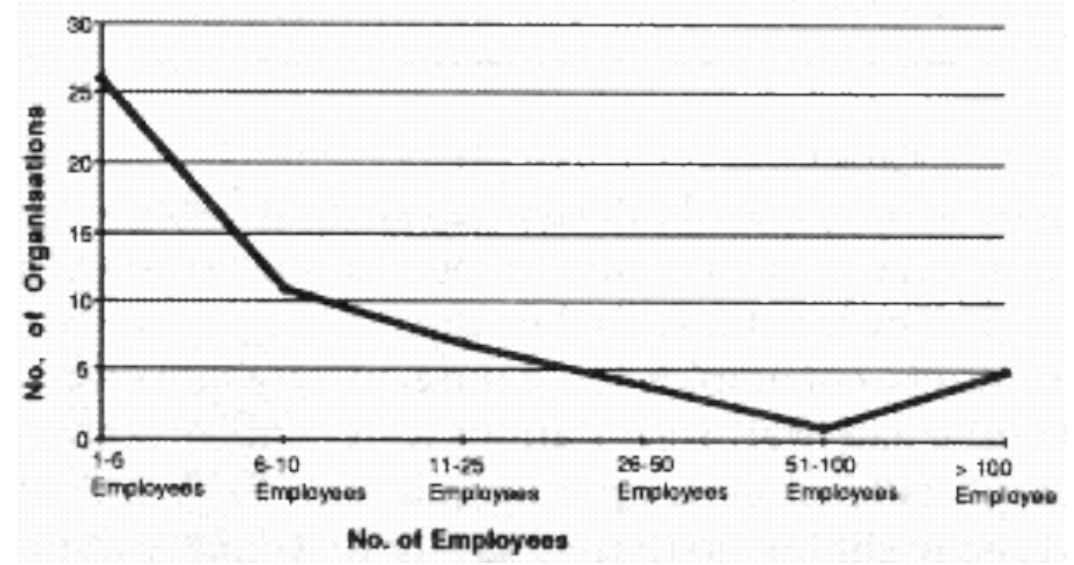

Figure IV Organisation employee size

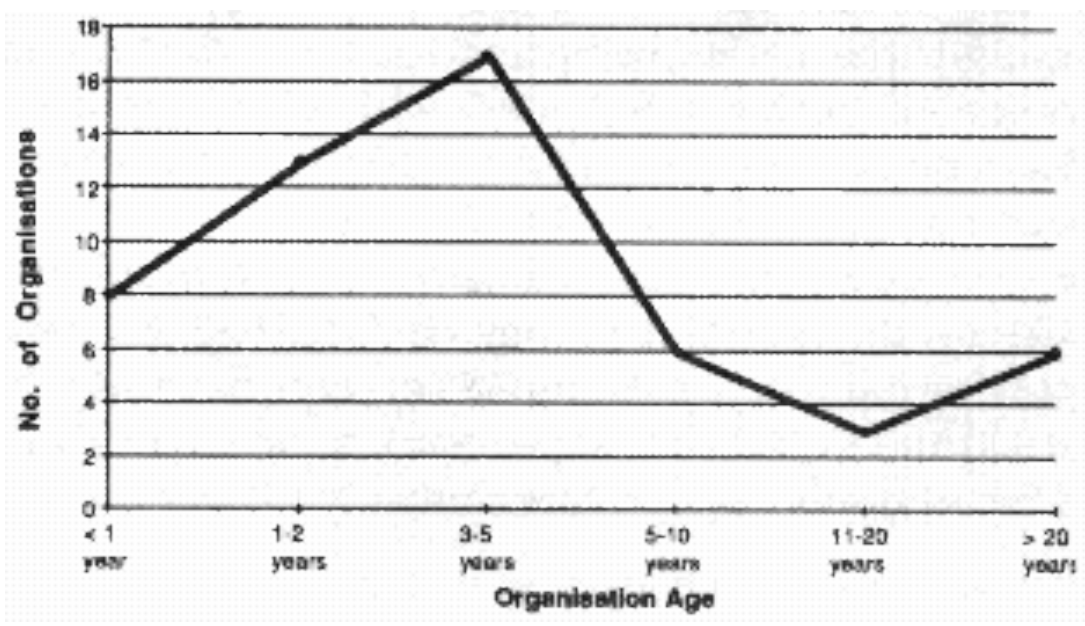

Figure V Organisation age

\section{Multimedia Personnel Base}

As part of the scope of this study was to provide a "snapshot" of industry indicators, it was thought to be useful to obtain information comparing the employee base of the industry to the contractors and consultants base. This was grounded on the assumption that employees represented more stability than contractors and consultants who operate on a project or case by case basis. It was hoped also that the results could provide some indication of how firms were willing to internalise some functions such as project management, but required external assistance for specialist knowledge in areas such as systems integration. 


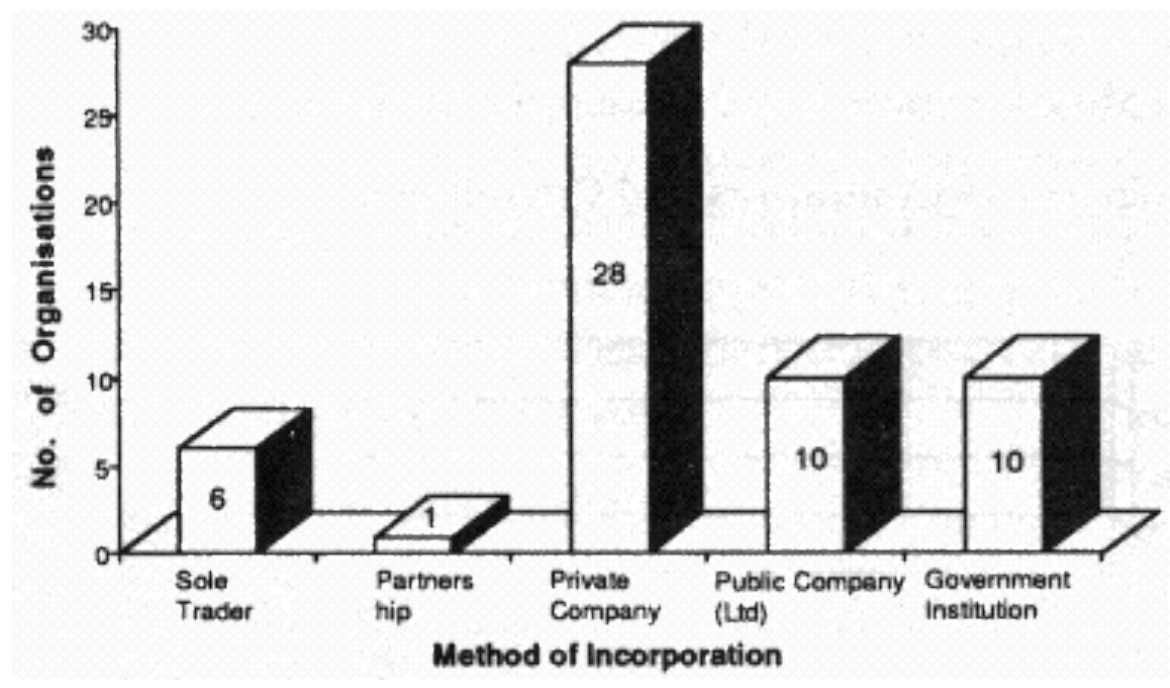

Figure 6 Incorporation of business activities

Figure Seven compares the number of employees to contractors in 10 separate categories nominated in the accompanying legend. Organisations categorised a total of 620 different employees, contractors and consultants for this component of the questionnaire. Internal employees represented approximately 70 per cent (442) of all personnel engaged by multimedia producers, while contractors and consultants represented 30 per cent (178). This figure could represent one of three things: firms had the resources to engage employees; projects were of a low risk or long-term nature and did not involve much contract work and these were internalised through employment; or skills shortages in the industry has led to a bias towards employment over contract work in order to secure key skills for multimedia production.

Interesting also is the difference in employment levels between groups. While the demand for employees follows a relatively stable progression across the ten occupational groupings, demand for contractors and consultants does not follows a similar pattern, lending support to the thesis that organisations internalise different risks and activities among employees and contractors. Ignoring unclassified (other) consultants and contractors, occupation groups $1,5,7$ and 8 for language specialists, technical team leaders, creative directors, and computer technical and software expertise have the highest contractor engagement in relation to the base of employees. Except for occupation grouping 1, it would appear that these generic groupings are already employed at high levels within firms, and may be called upon to work on a contract or case by case basis. Disregarding occupational grouping 10 (other functions), it appears organisations were least willing to externalise those functions most critical to the success of projects. As a proportion of employees, Groups 2, 3, 4, 6 
and 9 had the lowest ratio of contractors to employees. This would appear to indicate that telecommunications and broadcasting expertise, high level management roles such as executive producer and project management, and specialised personnel such as software design and development and information retrieval specialists were key to the success of many projects, regardless of their level of supply in the market.

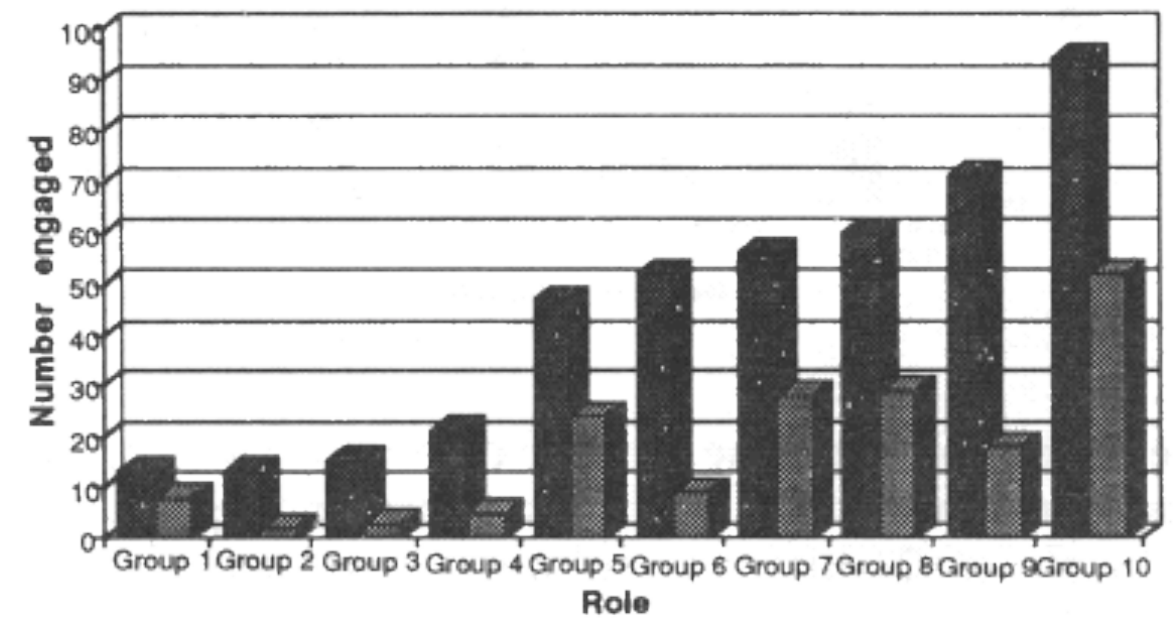

Figure VII Employees vs contractors and consultants

Figure VII Legend

Group 1 Language specialists / literary and story editor/key quality assurance role

Group 2 Librarian/Information retrieval specialist

Group 3 Telecommunications/broadcasting expertise

Group 4 R \& D/Computer Science orientation (hardware, operating systems, object oriented design)

Group 5 Technical team leader/audio and video know how / authoring tools / focus on software usability/QA

Group 6 Project manager/on-time and on-cost competence/ probably with TV/Film Experience

Group 7 Creative director/art director / graphic designer (product "look and feel")

Group 8 Computer technical expert creative systems designer/ systems integrator/broad based hardware and software knowledge/commercial know-how

Group 9 Executive Producer/publisher/negotiator of contracts / marketer/ business developer

Group 10 Other Functions 
Table $\mathrm{V}$ provides a picture of the highest educational qualifications attained by the 620 people working in the field of multimedia. The large percentage of unknown qualifications skews the data significantly (34 per cent) but conclusions can be drawn from the remaining results. Overall the multimedia field is extremely educated with 42 per cent of the total or 68 per cent of all known qualifications awarded at the University bachelor degree level or above. With an emerging gap between the demand for and supply of suitably qualified multimedia workers, one would expect this gap to be serviced by private colleges or informal training. Less than one per cent of multimedia personnel indicate that this is not the case.

Table V Organisation educational qualifications

\begin{tabular}{lcc} 
Qualification & $\begin{array}{c}\text { Organisation } \\
\text { total }\end{array}$ & Percentage \\
\hline Higher tertiary qualification (Doctorate or Masters) & 46 & $7.42 \%$ \\
University Bachelor Degree or Graduate Certificate & 262 & $42.26 \%$ \\
Diploma or Associate Diploma & 41 & $6.61 \%$ \\
Private college qualification & 6 & $0.97 \%$ \\
Higher School Certificate School & 41 & $6.61 \%$ \\
Certificate & 6 & $0.97 \%$ \\
No formal qualifications & 8 & $1.29 \%$ \\
Not known & 210 & $33.87 \%$ \\
\hline
\end{tabular}

\section{Project indicators}

Table VI and Table VII provide details of an organisation's project mix and typical project indicators. While no specific inferences can be drawn from these results, given the broad mix of projects undertaken by those surveyed, generalisations can be drawn from the data. Table VI indicates that the majority of current projects (67 per cent) undertaken by organisations may be described as those involving multimedia production. The focus of project types then tended to favour dedicated graphics or text productions (18 per cent) followed by an even mix of dedicated music, video, or other production.

Table VII provides results of four key indicators for a typical project. Respondents were asked to nominate key variables that typified a recent project undertaking or broadly represented their current mix of projects. Most undertakings ranged in cost from $\$ 10,000$ to over $\$ 100,000$ (76 per cent) with the mode being at the $\$ 10,000$ to $\$ 50,000$ range (33 per cent). A typical project engaged 1-10 persons in its production (96 per cent), and took from one month to a year to develop (75 per cent). By far the most popular implementation means was CD ROM (58 per cent) with few projects using the new technologies of on-line services of any description (13 per cent) or CD-I or Video-CD (6 per cent). 
Table VI Organisation project mix

Type of Project No. of Projects Percentage

Multimedia production

\begin{tabular}{cc}
260 & $66.84 \%$ \\
28 & $7.20 \%$ \\
69 & $17.74 \%$ \\
32 & $8.23 \%$ \\
\hline
\end{tabular}
$66.84 \%$

Dedicated music or video

Other production $8.23 \%$

Table VII Typical project indicators

\begin{tabular}{lcc} 
Cost & $\begin{array}{c}\text { No. of } \\
\text { Organisations }\end{array}$ & Percentage \\
\hline$<\$ 2,000$ & 3 & $5.88 \%$ \\
$\$ 2,001-\$ 5,000$ & 7 & $13.73 \%$ \\
$\$ 5,001-\$ 10,000$ & 2 & $3.92 \%$ \\
$\$ 10,001-\$ 50,000$ & 17 & $33.33 \%$ \\
$\$ 50,001-\$ 100,000$ & 10 & $19.61 \%$ \\
$>\$ 100,000$ & 12 & $23.53 \%$ \\
\hline
\end{tabular}

Employees/Contractors

\begin{tabular}{lcc}
\hline $1-2$ persons & 11 & $21.57 \%$ \\
$3-5$ persons & 26 & $50.98 \%$ \\
$6-10$ persons & 12 & $23.53 \%$ \\
$11-30$ persons & 2 & $3.92 \%$ \\
$31-50$ persons & 0 & $0.00 \%$ \\
$>50$ persons & 0 & $0.00 \%$ \\
\hline
\end{tabular}

Time Period

$<1$ month

1-6 months $9.80 \%$

7-12 months $52.94 \%$

1-2 years

$21.57 \%$

3-5 years $11.76 \%$

$>5$ years

$3.92 \%$ $0.00 \%$

End-Media Employed

CD ROM

CD-I or Video-CD

On-line services

Floppy / Hard Disk

Other

$\begin{array}{cc}5 & 9.80 \% \\ 27 & 52.94 \% \\ 11 & 21.57 \% \\ 6 & 11.76 \% \\ 2 & 3.92 \% \\ 0 & 0.00 \%\end{array}$

\section{Summary of key findings}

The following provides a more concise view of the study's otherwise comprehensive findings. While the sample size of 54 respondents is a limited basis from which to extrapolate more general findings, the results 
provide an insight to the Australian interactive multimedia base from which the respondents were drawn.

The majority of firms surveyed appeared to concentrate on provision of products and services in the field if interactive multimedia training and education (57 per cent), information kiosks and directories (52 per cent), and commercial CD ROM titles (39 per cent). In terms of industry specialisation, firms nominated education (65 per cent), government (52 per cent), and consumer products such as entertainment systems and games (41 per cent) as the core area of market orientation.

In terms of specialisation by activity in multimedia content development, respondents indicated that tasks ranging from project planning and design (78 per cent), writing, scripting and titles development (76 per cent) through to other areas of the development process were important activity foci. Management consultancy and post-production services were of lesser concern (33 and 22 per cent respectively).

Australian firms see the domestic Australasian market as the target market for their development products (90 per cent). To a lesser degree firms seek to leverage content investments in the English-speaking markets of Europe and North America (54 per cent). A majority of firms see English language as their core direction, while the emerging markets of Asia are potentially strategic (45 per cent) though non-English language title expertise is of secondary concern (33 per cent).

In terms of demographic indicators, the typical multimedia content developer is a small concern, employing one to five persons (48 per cent), has an annual turnover of between $\$ 100,000$ and $\$ 1,000,000$ (50 per cent), is one to five years of age (56 per cent) and is incorporated as a private company (51 per cent). Over 70 per cent of those people engaged by multimedia producers are employees of the firm, the remaining 30 per cent are contractors or consultants. Contractors are generally more prevalent in occupational groupings that exist in high numbers as employees, probably to supplement the firm's resources in times of additional work. Contractors are least likely to be engaged in "strategic" areas of the production process, particularly in specialist areas of design, or key areas of project management. Of all known educational qualification held by multimedia professionals, over 68 per cent hold a bachelor degree or higher awarded from a university.

Organisations typically allocate 67 per cent of their projects to multimedia production. The remainder of their expertise is spread evenly among projects involving dedicated music, video, graphics, text, or other productions. A typical project costs between $\$ 10,000$ and $\$ 100,000$ (76 per cent), involves 1-10 persons in its production (96 per cent), takes from one month to one year to develop (75 per cent), with the end-media employed being CD ROM (58 per cent). 


\section{Policy implications and future research}

The results of this study hold implications for government programs supporting new multimedia ventures, and for present policy and strategy mechanisms employed by multimedia producers. The study also provides a solid grounding on which to conduct future research in the field particularly to evaluate the effects of policy over time with regard to multimedia.

\section{Government programs}

At present there are a range of government programs that target the unique needs of multimedia producers in Australia. Additionally there are a series of discussions and inquiries currently underway that see multimedia as a strategic concern for their investigations. These include, but are not limited to the Broadband Services Expert Group's inquiry; the 1997 telecommunications policy review; the DIST study of interactive multimedia industry opportunities; the former Prime Minister's cultural policy; Commerce in Content; Excellence in Content; and the Communications Futures Project to name but a few.

The rewards and incentives proposed under these investigations are not trivial. Initiatives announced in Creative Nation included important undertakings such as the establishment of the Australian Multimedia Enterprise and \$252 million in arts funding. A primary concern of a majority of the current inquiries is not only the strategic nature of multimedia but the corresponding opportunities for overseas export revenue, particularly in the markets of Asia. Three key observations from this study would seem to undermine confidence in these predictions.

Firstly, the Australian multimedia industry consists primarily of smaller firms, both in terms of their annual turnover, personnel base, titles produced, or their experience in the market. Secondly Australian producers are extremely limited in their scope, primarily concentrating on the local market for their products and services. Thirdly a majority of firms are concentrating on training and education, kiosks and directories, and customised solutions. While a significant proportion are concentrating on commercial titles, they do not have the size or experience to compete on international markets. The high attrition rate between market entry and profitability in Australian firms would further suggest they will be unable to serve international content markets. Finally Commerce in Content argues that the multimedia industry will follow the music industry model, where approximately 20 firms will control the distribution of multimedia titles, locking out smaller publishers.[32]

Where does this leave Australian industry policy? Will our multimedia industry realise success on the international market? Do we have the skills base to compete in the established North American market? Will Australian multimedia, which stands at a cross-roads, become a victim of 
well-meaning, but ill-conceived government support like the software industry generally did in 1983? Will multimedia remain a highly localised concern for years to come? Has Australia the drive and ambition to undertake significant risks to realise significant returns in multimedia? There are no obvious answers to these questions, but they bring into question the entire scope and goals of Australian industry policy in multimedia.

\section{Suggestions for future research}

This study has primarily "tested the water" in the Australian multimedia industry. It has attempted to provide a broad overview of certain trends in multimedia, and examine the "current state of play" in the field with regard to multimedia content developers in terms of size, composition, information flows, types of activities undertaken, technological orientation, and project focus. The results, while interesting, require further research and comparison, particularly on an international level.

The obvious area for further investigation is in targeting Australian industry policy, and linking this with actual outcomes in multimedia. While other studies have identified constraints to Australian multimedia, particularly in terms of distribution, access to venture capital (a recurrent theme in high technology generally), and intellectual property rights, more research needs to be undertaken on the peculiar problems facing the industry. Finally, if Australia's success lies in exporting commercial titles, or indeed services, one needs to question how we can best utilise our limited skill base in targeting this aim, and where Australia's natural advantage lies in this unique field.

\section{Conclusions}

The first component of this study addressed the economic and cultural arguments used to sustain the view that a thriving indigenous multimedia industry was required in the Australian context. Part two examined the lessons of past discontinuous technologies, categorised multimedia growth into the three main phases of CD ROM, on-line PC services, and broadband interactive services, then attempted to plot the current position of the Australian multimedia industry against this schema. Part three examined trends in multimedia, particularly the requirements of the model for the realisation of a mass market, the interests of consumer titles as a key driver, and the necessity for excellence in content as a determinant for further progress in the field. The final component of the study involved interpreting the results of a questionnaire targeted towards multimedia content developers in order to examine the Australian multimedia industry.

The findings of this study are significant. While there are important opportunities in the multimedia field, the Australian market is not yet of sufficient size or maturity to tackle the demands of world-class content 
that satisfies the requirements of mass-markets in a global environment. While the Australian experience indicates that its industry has a broad commercial base with a strong publications focus, the players are small concerns concentrating on highly localised content for specific purposes, and few successes have resulted in global distribution of generic commercial titles appropriate for a world audience, capable of generating significant returns on investment. The recommendation is that Australian industry policy should concentrate on developing those skills appropriate for a world-class multimedia industry, if it is to compete in such global markets. There are excellent opportunities in this field for how Australia might best take stock of these emerging markets.

\section{References}

Anonymous. "Media leaders see tech trends impacting content. (CMP Networked Economy conference)." Interactive Content, Oct 1994, Vol 1 (6) p.29.

Anonymous. "Multimedia slow to take off in college market, study says." Multimedia Business Report, Vol 4 (2), 13 Jan 1995, p.5.

Commonwealth of Australia, Creative Nation - Commonwealth Cultural Policy. October 1994, pp.l-6.

Commonwealth of Australia, Introducing Multimedia, BDP 1992-1994.

Coopers \& Lybrand, Multimedia Industry Group. Excellence in Content - The focus for Australian investment in Multimedia Content. Coopers and Lybrand, June 1995.

Cutler \& Company Pty Ltd. Commerce in Content - Building Australia's International Future in Interactive Multimedia Markets. September 1994.

Elgan, Mike. "CD ROMs are slick. Exciting. Popular. And far too often, trash." Windows Magazine, Vol 6(4) April 1995, p.45.

Gale, Michael. Press Release, Double Impact Multimedia 1995.

Hamm, Steve. "A Serious Business - Firms Focus Multimedia Development on the Corporate Market." PC Week, Feb 13, 1995, Vol 12(6).

Johnson, Ian. "Multimedia remains in its infancy despite all the hype it has received," Computing Canada, Vol 21(2) January 18, 1995, p.14.

Keating, Paul J. Press Release. Office of the Prime Minister of Australia, October 20, 1994.

Maciag, Gregory A. "CD ROM is music, both literally and figuratively." National Underwriter, Vol 98(24), 13 June 1994, p.26, 39.

Market Vision. Multimedia Applications and Markets - 1994 Annual Forecast. Market Vision, 1994.

Morgenstern, David. "Conference charts future of Cds: CD ROM drives sell mostly to homes. (Dataquest StorageTrack '94 Conference)." MacWEEK, 22 August, 1994, Vol 8(34)p.6(1).

Schmukler, Mark. "Compact Disc Technology Offers New Distribution Option." IMC Journal, Vol 20(5) Sept/Oct 1992, pp.24-25. 
SIMBA Information. Publishing for the College Market: 1994-1995 Review, Trends Forecast, 1995.

Somerson, Paul. "Seven CD Sins." PC-Computing, March 1995, Vol 8(3), p.47.

Stankiewicz, S. "CD ROM Drives Sell with a Vengeance," Computer Shopper, August

Strothman, J. "CD-R Hardware and Software Prices Plunge," Computer Pictures, Vol 12(3) 1994, pp. s12-s13.

TFPN Publishing, Facts and Figures 1994. London 1994.

Worthington, Paul. "Big Time or Bust." Multimedia World, Vol 2(1) Dec 1994, p.162.

Young, Lewis H. "Convergence Drives the US Economy." Electronic Business Buyer, Convergence Supplement, Nov 1994, pp.S4-S7.

Young, Robbin. "Catching the Content Wave," Windows Watcher Vol 4(9), October 1994, p.1-2.

\section{Notes}

1. TFPN Publishing, Facts and Figures 1994, London 1994.

2. Michael Gale, Press Release, Double Impact Multimedia 1995.

3. Commonwealth of Australia, Introducing Multimedia, BDP 1992-1994.

4. Paul J. Keating. Press Release. Office of the Prime Minister of Australia, October 20,1994.

5. Commonwealth of Australia, Creative Nation - Commonwealth Cultural Policy, October 1994, pp.1-6.

6. Lewis H. Young. "Convergence Drives the US Economy." Electronic Business Buyer, Convergence Supplement, Nov 1994, pp.S4-S7.

7. Ian Johnson. "Multimedia remains in its infancy despite all the hype it has received," Computing Canada, Vol 21(2) January 18, 1995m p.14

8. Joanna Tamer. "Consumer Titles: The End of a Pioneering Era?" CD ROM Professional Magazine, March 1995.

9. J. Strothman. "CD-R Hardware and Software Prices Plunge," Computer Pictures, Vol 12(3)1994, pp. sl2-s13.

10. S. Stankiewicz. "CD ROM Drives Sell with a Vengeance," Computer Shopper, August 1994, p.65.

11. Gregory A. Maciag. "CD ROM is music, both literally and figuratively," National Underwriter, Vol 98(24),13 June 1994, p.26, 39.

12. Inteco Corporation, cited in David Rosen and Caryn Mladen, Making Money with Multimedia, Addison Wesley Ltd, 1994, p.134.

13. Robbin Young. "Catching the Content Wave," Windows Watcher Vol 4(9) October 1994 p.1-2.

14. Commonwealth of Australia, Introducing Multimedia, (CD ROM) BDP 19921994.

15. Market Vision. Multimedia Applications and Markets - 1994 Annual Forecast, Market Vision, 1994.

16. Steve Hamm. "A Serious Business - Firms Focus Multimedia Development on the Corporate Market." PC Week, Feb 13,1995, Vol 12(6).

17. Mark Schmukler. "Compact Disc Technology Offers New Distribution Option " IMC Journal, Vol 20(5), Sept/Oct 1992, pp.24-25.

18. TFPN Publishing, Facts and Figures 1994, London 1994.

19. TFPN Publishing, Facts and Figures 1994, London 1994.

20. Michael Gale, Press Release, Double Impact Multimedia 1993. 
21. Robbin Young. "Catching the Content Wave," Windows Watcher, Vol 4(9)

October 1994 p.1-2.

22. Ian Johnson. "Multimedia remains in its infancy despite all the hype it has received," Computing Canada, Vol 21(2) January 18, 1993, p.14.

23. David Morgenstern "Conference charts future of Cds: CD ROM drives sell mostly to homes. (Dataquest StorageTrack '94 Conference)." MacWEEK, 22 August, 1994, Vol 8(34), p.6 (1).

24. Anonymous. Media leaders see tech trends impacting content (CMP Networked Economy conference). Interactive Content, Oct 1994, Vol 1(6), p.29.

25. Robbin Young. "Catching the Content Wave," Windows Watcher, Vol 4(9) October 1994 p.1-2.

26. Coopers \& Lybrand, Multimedia Industry Group, Excellence in Content - The focus for Australian investment in Multimedia Content. Coopers and Lybrand, June 1995.

27. Paul Worthington. Big Time or Bust. Multimedia World, Vol 2(1), Dec 1994, p.162.

28. Mike Elgan. CD ROMs are slick. Exciting. Popular. And far too often, trash." Windows Magazine, Vol 6(4) April 1995, p.45.

29. Paul Somerson. Seven CD Sins. PC-Computing, March 1995, Vol 8(3), p.47.

30. Anonymous. Multimedia slow to take off in college market, study says. Multimedia Business Report, Vol 4(2), 13 Jan 1995, p5.

31. SIMBA Information. Publishing for the College Market: 1994-1995 Review, Trends E Forecast, 1995.

32. Cutler \& Company Pty Ltd. Commerce in Content - Building Australia's International Future in Interactive Multimedia Markets. September 1994.

Author: Dean Jason Noacco can be contacted through Department of Information and Communication Technology, Faculty of Informatics, University of Wollongong, Wollongong NSW 2522. Phone 042-214142; email d.noacco@uow.edu.au

Please cite as: Noacco, D. J. (1995). Multimedia markets: A study of Australian content developers. Australian Journal of Educational Technology, 11(2), 52-74. http: / / www.ascilite.org.au / ajet / ajet11 / noacco.html 